\title{
Relationship Between Asymmetric Information and Equity Returns in the Kenyan Capital Market. A Cointegration Approach
}

\author{
Peter Kamau Ndichu $^{1 *} \quad$ Dr. Destaings Nyongesa ${ }^{2}$ \\ 1.Department of Accounting and Finance, Maseno university, P.O. Box 333 -40105 Maseno \\ 2.Department of Economics, Maseno university, P.O. Box 333 -40105 Maseno
}

\begin{abstract}
This paper sought to investigate the cointegration relationship between asymmetric information and equity returns. Previous literature has shown asymmetric information influences Assets returns but it is less known whether there exists a long run relationship between these variables. In this regard stationarity tests and Johansen cointegration test were employed to ascertain whether there exists a long run relationship between the two variables. Data composed of monthly transaction on the 20 equities used in formulation of the NSE 20 share index over the period between Jan 2009 and up to March 2018 which formed 111 data points. The results showed that equity returns were stationary at levels using the Augmented Dickey Fuller Test, Phillip-Perron and KPSS while Asymmetric information was non-stationary at levels, but stationary at first difference. The results also showed that Asymmetric information weakly positively correlated and insignificant, $r(99)=.08, p=.35$ with equity returns using Pearson's correlation coefficient. Johansen Cointegration test indicated existence of a cointegrating equation indicating a significant long run relationship between asymmetric information and equity where decrease of $0.0093 \%$ in asymmetric information is associated with an increase in equity returns in the long run and vice versa. We conclude there is a significant long run relationship between asymmetric information and equity returns.
\end{abstract}

Keywords: Asymmetric information, Equity returns.

DOI: $10.7176 /$ RJFA/12-18-07

Publication date:September $30^{\text {th }} 2021$

\section{Introduction}

Asymmetric information is a state where one party has or will have a greater level of knowledge relative to another party about their own characteristics or actions (Brown, 2016). World Bank (2003) defines asymmetric information, as the adjective indicates, refers to situations, in which some agent in a trade possesses information while other agents involved in the same trade do not. Asymmetric information can be defined as a situation which one party to a transaction has information about a transaction to which other party is not privy to, which results in a bad deal for one party often but not always the buyer, (Farlex, 2012). (Akerlof, 1970) demonstrates that markets may break down completely in the presence of asymmetric information and three distinct consequences emerging, adverse selection, moral hazards and monitoring. According to Aboody \& Baruch, (2000) adverse selection occurs when there is a lack of symmetric information to a deal between the buyer and seller, whereas moral hazard occurs when there is asymmetric information between two parties and change in behaviour after a deal is struck and as such these asymmetries create inefficiencies in price, value and quality of goods and services. Easley \& O'Hara (2004) posit that investors demand a premium in holding stocks with less public information, because uninformed investors experience an informational disadvantage compared to informed investors who are in a better position to adjust their portfolio to incorporate new information. (Brown, Hillegeist, \& Lo, 2008), presents two proxy measures for asymmetric information, bid -ask spread and probability information trading (PIN). Johnson \& So (2017) outlines a simple measure the multimarket information asymmetry (MIA) measure but it requires access to option trading volume in addition to equity trading volume, since it is based on the relative daily trading volumes in options and stocks. Bommel \& Lof (2018) proposes volume coefficient of variation (VCV) as a novel measure of the proportion of information trade it is a preferred measure due to its computational simplicity and requires only observation of trading volume as opposed to quotes, prices or signed order flow.

Much of literature asserts that asymmetric information positively influences asset returns resulting in excess returns (Morse, 1980; Easley et al, 2002 Chan et al, 2008; Easley et al, 2011; Li et al, 2014; Nuryaman, 2014). This may hold true in the short run according to Morse, (1980) where successful trading on asymmetric information exists for shorter periods of time in securities markets. Asset returns may experience a weak effect due to Asymmetric information (Zheng \& Narayan 2011). Costs of equity capital is positively influenced by Asymmetric information where the higher the asymmetric information the higher the cost of equity capital (Nuryaman, 2014) though bonds show a weaker response to joint bad news than equities (Cappiello, Engle \& Sheppard, 2003). Firms with high asymmetric information show a more pronounced announcement effects that 
those with low asymmetric information ( $\mathrm{Yu}, 2012$ ), this correlates with the fact that the more asymmetric information the institutional investors have, the stronger the correlation between the institutional ownership and firm-specific return volatility (Ding, 2011). Foreign returns cause movements in domestic markets (Connolly \& Wang. 2003) where public news about U.S. money and equity markets affects equity markets abroad (Andersen et al. 2003). Increase in default rate in the banking sector can be attributed to asymmetric information (Kemei, 2014).

While researchers have attributed excess asset returns to asymmetric information (Morse, 1980; Easley et al, 2002 Chan et al, 2008; Easley et al, 2010; Li et al, 2014; Nuryaman, 2014, Johnson \& So, 2017 Bommel \& Lof, 2018) existing literature does not explore the effect of asymmetric information and equity returns in Kenyan capital markets. Chan et al, (2008) focuses on foreign share discount and not asymmetric information and asset return and further present cross-sectional data but does show results on time series data. Li et al, (2014), uses adjusted probability information trading and fails to report on the effect of volume coefficient of variation (VCV) of informed trading, as a measure of asymmetric information time series data results are lacking since they present cross sectional stock results. Nuryaman, (2014) reports on cost of equity capital and the effect of asymmetric information on earnings management but does not give results on asymmetric information and asset returns, Nurmayan (2014) further present results using bid ask spread as proxy for asymmetric information, however results on volume coefficient of variation (VCV) trading is lacking. Kemei \& Kerongo (2014) focuses on asymmetric information and performance of banks, and does not consider equity returns, they also use descriptive research design but fail to present results using correlational design. Johnson \& So (2017) proposes a simple measure but requires option trading to execute and Bommel \& Lof, (2018) focus on the asymmetric information measures and does not focus on the effect between asymmetric information and equity returns. The effect between asymmetric information and equity returns in Kenyan capital markets is, therefore, unclear and further the long run relationship between the two variables is less known.

Empirical literature posits that presence of asymmetric information is key in determining the returns of asset especially equity returns. Investors engaging in an equity market with high levels of asymmetric information returns will have above normal returns on the securities they have transacted in. prior studies use cross sectional data, adjusted probability information trading, and descriptive design, however they do not present results volume coefficient of variation (VCV) Correlational design results and time series data results are lacking.

Kenya's Market Capitalization accounted for $26.1 \%$ of its Nominal GDP in Dec 2019, compared with a percentage of $23.6 \%$ in the previous year. (CEIC, 2020) This is a dismal performance noting that a Stock market capitalization of about 50 percent of GDP and more is an indication of a well-developed stock market. Previous years also present performance below50\%, for instance in 2009(29.1\%), 2010(36.8\%), 2011(23.4\%), 2012(29.8\%), 2013(40\%), 2014(42.6\%), 2015(32.6), 2016(27.5\%) and 2017(30.8\%) (World Bank, 2020)

Kenyan capital market, has witnessed low levels of participation in the capital markets in relation to knowledge and attitudes of the capital markets despite there being investor education programs undertaken by market players. According to Capital Market Investor Behavioural and Situational Analysis 2017/2018 Study reveal that regulators and private sector intermediaries in the financial services sector do conduct independent education and sensitization on various market segments but the impact on the financial health of consumers has been low for a number of reasons including: poor content design and delivery, low budgeting, fragmented approach, use of complex language and lack of customer focus. (CMA, 2020).

\section{Review of Literature}

\subsection{Theoretical Review}

\subsubsection{Efficient Market Hypothesis}

Most of the early work related to efficient capital markets was based on the random walk hypothesis, which contended that changes in stock prices occurred randomly. This early academic work contained extensive empirical analysis without much theory behind it. An article by Fama (1970) attempted to formalize the theory and organize the growing empirical evidence. Fama presented the efficient market theory in terms of a fair game model, contending that investors can be confident that a current market price fully reflects all available information about a security and, therefore, the expected return based upon this price is consistent with its risk. In his original article, Fama, (1970) divided the overall efficient market hypothesis (EMH) and the empirical tests of the hypothesis into three sub hypotheses depending on the information set involved: (1) weak-form Efficient Market Hypothesis (EMH), (2) semi-strong-form EMH, and (3) strong-form EMH. In a subsequent review article, Fama (1991a) again divided the empirical results into three groups but shifted empirical results between the prior categories.

In capital markets the EMH may be applied. While other markets are often analysed from the perspective of the allocation efficiency, the present market efficiency is primarily associated with the cost efficiency (Blume \& Durlauf, 2008). According to (Goedhart, Koller \& Wessels, 2010) an efficient stock market is a market where stock prices reflect fundamental information about companies and in such a case, the market value of the 
company changes in a way very similar to that of the intrinsic value of a company. Such changes are not consistent with the value and do not restrain from trading financial assets. (Goedhart, Koller, Wessels, 2010) continues to assert that the differences in investor awareness and uneven transaction costs prevent fundamental changes in value to be completely and immediately reflected in market prices, however, if markets are efficient, changes in asset prices cannot be reflected in algorithms, while excess return is gained as a success rather than an outcome of a correct prediction. A market is efficient when it is not possible to earn a return higher than the market return (Allen, Brealey \& Myers, 2011). In other words, the value of shares reflects the fair value of the company and is equal to the future cash flows discounted by an alternative cost of capital. According to Eakins \& Mishkin, (2012) an efficient market is a market where asset prices fully reflected all information available. Essentially in efficient markets available information is already incorporated in asset prices eliminating traces of asymmetric information and that investors cannot earn a risk weighted excess return (Eakins \& Mishkin, 2012)

Market efficiency is usually broken down into three levels; weak, semi-strong, and strong forms considering information reflected in market prices. In weak form, the current security price or asset price reflects all information related to the price changes in the past, such information includes data on previous price, trading volume etc. and therefore it is impossible to make excess profits in a securities market. Consequently, if the market is weakly, efficient, technical analysis yields no excess return (Degutis \& Novickyte, 2014). When current security prices reflect not only information about historical prices but also current publicly available information such as announcements of acquisition and mergers, dividend pay-outs and changes in accounting policy. then the efficiency in the market is said to be semi strong (Degutis \& Novickyte, 2014). Finally, markets are said to be strongly efficient when current securities prices reflect all possible information which does not necessarily have to be public, consequently this implies that it is impossible to earn excess profit while trading on insider information which seems to be unlikely (Malkiel, 2011). Empirical studies have revealed weak form of market efficiency in different capital markets and in addition this form of market efficiency is among assumptions in the valuation of stocks and options (Palan, 2004). On the other hand, (Schwert, 2003) posits that the strong form of market efficiency is possible since insider trading is not legal. (Eakins \& Mishkin, 2012) concludes that the results of the semi-strong market efficiency studies vary considerably, results indicate market inefficiencies.

Degutis \& Novickyte, (2014) argues that absolute or partial rationality of market participants is essential for its efficiency though not all market participants are rational, resulting in part of trades being not based on a rational analysis. On the other hand, the trades of irrational investors are random, which should not influence the securities price. According to Shleifer (2000) a share price is positively affected by a random purchase, it will adversely be negatively affected by a random sale, because the probability of random purchase and random sale is the same. In terms of trading methods, investors can be grouped into informed investors and noise traders. Informed investors rely on fundamental analysis while noise traders do not consider all available information when trading (Degutis \& Novickyte, 2014). According to Goedhart, Koller \& Wessels (2010) investors are divided into intrinsic value investors, traders, and mechanical investors, the intrinsic value investors ground their trading decisions on a fundamental analysis, while traders use technical analysis, and mechanical traders exercise trades according to rules e. g., index replication.

The study conducted by Goedhart, Koller \& Wessels (2010) shows that it was the intrinsic value investors who have a major impact on securities prices as their trades were concentrated and large. Thus, even though the existence of irrational investors is generally recognized, their influence on securities prices is often considered to be negligible though not in behavioural finance. This conclusion is closely related to the arbitrage theory which assumes irrational investors creating risk-free profit opportunities for others. Sophisticated investors spot these opportunities and eliminate irrational prices by trading mispriced securities. The EMH is also closely linked with the capital asset pricing model (CAPM) and securities substitution theory. The CAPM is often employed to measure the risk in testing the efficient market hypothesis.

In conclusion EMH's concept of informational efficiency has a counter-intuitive flavor to it: the more efficient the market, the more random the sequence of price changes generated by such a market, and the most efficient market of all is one in which price changes are completely random and unpredictable. This is not an accident of nature, but is in fact the direct result of many active market participants attempting to profit from their information. Driven by profit opportunities, an army of investors try to capitalize on even the smallest informational advantages at their disposal, and in doing so they incorporate their information into market prices and quickly eliminate the profit opportunities that first motivated their trades. If this occurs instantaneously, which it must in an idealized world of 'frictionless' markets and costless trading, then prices must always fully reflect all available information. Therefore, no profits can be garnered from information-based trading because such profits must have already been captured. In mathematical terms, prices follow a martingale which is a model of a fair game where knowledge of past events never helps predict future winnings (Gosalia \& Lefebvre, 2013).

According to the EMH, by using available information, all market participants arrive at "rational 
expectations" forecasts of future security returns, and these forecasts become fully reflected in the prices that are observed in financial markets, (Malkiel, 2003). Changes in asset prices will occur on account of news which cannot be predicted in any systematic manner. In other words, asset prices respond only to the unexpected part of any news, since the expected part of the news is already embedded in prices, (Malkiel, 2003). However empirical studies supporting the notion of randomness in security prices focused on measures of short run serial correlations between successive security price changes, (Malkiel, 2003). The conclusion of these studies supported the view that stock markets have no memory and therefore how stocks behaved in the past is not useful in divining how it will behave in the future, (Cootner, 1964; Lo \& MacKinlay, 1999). Lo, et.al (2000) find that stock signals may actually have some modest predictive.

Behaviorist find this short-run momentum to be consistent with psychological feedback mechanisms such that individuals see a stock price rising and are drawn into the market in a kind of "bandwagon effect," (Malkiel, 2003). Shiller (2000) describes the rise in the U.S. stock market during the late 1990s as the result of psychological contagion leading to irrational exuberance. The behaviorists offered another explanation for patterns of short-run momentum a tendency for investors to underreact to new information. If the full impact of an important news announcement is only grasped over a period of time, stock prices will exhibit the positive serial correlation found by investigators.

Evidence of negative serial correlation, return reversals over longer holding periods exist, (Fama and French, 1988; Poterba and Summers 1988). This have been attributed to forecast ability to the tendency of stock market prices to "overreact." Malkiel, (2003) asserts that investors are subject to waves of optimism and pessimism that cause prices to deviate systematically from their fundamental values and later to exhibit mean reversion and also this view further support the notion that investment techniques that rest on a "contrarian" strategy, that is, buying the stocks, or groups of stocks, that have been out of favor for long periods of time and avoiding those stocks that have had large run-ups over the last several years.

Stock market returns in January has been very unusual, where returns from an equally weighted stock index have tended to be unusually high during the first two weeks of the year, especially stocks with relatively small total capitalizations, (Malkeil, 2003).Malkiel, 2003 further asserts that these predictable patterns or anomalies, are not dependable from period to period and do not appear to offer arbitrage opportunities that would enable investors to make excess risk adjusted returns.

The theory presents evidence that information is frictionless where and individual investor while investing, can either have strong, semi strong or weak position. However the investor can be irrational while investing and hence does not necessary follow the information that the market presents, and further the assumption that the information is universally shared may not hold since various investors can hold information to benefit themselves in order to take advantage of the market. Still on the assumption that information follows a random walk may not be necessary true since investors have taken advantage of company announcement and press releases where negative information rationally may mean that the returns will be lower, which is not the case for companies presumed to be growth companies. Informed traders may transact at lower cost hence there is ease in exchange of securities and hence excess return in equity returns. Therefore, there is need analyse asymmetric information affect returns in Kenyan capital markets.

2.1.2 Empirical review of the Effect of Asymmetric Information on Equity Returns.

Coopers, Downs \& Patterson (1998) examine asymmetric information and the predictability of real estate returns, they employ a filter-rule methodology to determine predictability in returns and augment the return-based conditioning set with trading volume. They also construct a data set of Wednesdays close to Wednesday-close weekly returns and weekly volume for 301 Real Estate Investment Trusts (REITs) in the CRSP file between 1973 and 1995. They find that the predictability of real estate returns is generally more indicative of portfolio rebalancing effects than an adverse selection problem, there is a lack of literature on asymmetric information on returns on stocks.

Yang, et.al (2008) examine the effect of asymmetry information on equity prices in the local A- and foreign B-share market in China. They construct measures of information asymmetry based on market microstructure models i.e., the price impact coefficient, the adverse selection component (AS) of the spread, and the probability of informed trading (PIN), using data from January 2000 to November 2001 for 76 Chinese firms. They find that that all the measures of information asymmetry explain a significant portion of the cross-sectional variation in foreign share discounts. On a univariate basis, the price impact (PI) and the AS component are particularly strong, explaining $44 \%$ and $46 \%$ of the variation in B-share discounts, while the PIN explains $8 \%$. On a multivariate basis, the PI and the AS component are statistically more significant than any of the control variables in explaining B-share discounts. They also find that the advent of supposedly better-informed domestic investors in the B-share market should lead to a higher PI and AS component of the spread, as market makers in the B-share market now also face order flow from the better-informed domestic investors. They conclude that the two information asymmetry measures explain the cross-sectional variation in foreign share discounts, which indicates that information asymmetry is priced in international equity markets. The main focus of the study is on 
international markets but literature on Kenya which is perceived to be developing is lacking.

Zheng \& Narayan (2009) studied the relationship between asymmetric information and market collapse an evidence in the Chinese market, specifically studying the Shanghai stock exchange (SHSE), using data for the period January 1995 to May 2009. They develop the relationship between the illiquidity factor, asymmetric information, and market collapse. Their results show that systematic differences in the market risk-adjusted average returns of the liquidity-beta-sorted portfolios because the liquidity risk factors are priced. They also found out that contrary to the theoretical conjecture, asymmetric information has a very weak effect on market returns on the SHSE, they find that in only around $11 \%$ of cases asymmetric information has a statistically significant negative effect on market returns. The study contrast with other authors that asymmetric information affects returns and an examination of this variable in a Kenyan setting would enrich the existing literature a great deal.

Stroebel \& Kurlat (2013) study equilibrium asset market outcomes when there is heterogeneity in information about asset values among both buyers and sellers. Their first dataset contains the universe of ownership-changing housing deeds in Los Angeles County between June 1994 and the end of 2011 and the second dataset contains the universe of residential tax-assessment records for the year 2010, from these they find that Sellers are better informed than buyers about both the neighbourhood component and the structure component of the value of a house, but both among buyers and among sellers some are better informed than others. They also find that the correlations between buyer, seller and house characteristics and house prices are consistent with the patters than one would predict under these conditions. In particular, this indicates that asymmetric information about neighbourhood characteristics is an important aspect of real estate markets, and that heterogeneity in information across different agents can have significant distributional consequences.

Li et.al (2014) examine the impact of both Asymmetric information, illiquidity and asset returns evidence from Chinese market, using data period from 1 June 1999 to 31 December 2006 they find that stocks with higher information asymmetry experience higher excess returns. They also find that illiquidity also significantly impacts stock returns. They also conjecture the effect of both illiquidity and information asymmetry on stock returns will be weakened in the Chinese stock market after the split-share structure reform, given that investors' investment opportunity has increased and the trading volume has increased during this process. Literature on the two variables used together is lacking for Kenyan Capital markets.

From the foregoing research Cooper et.al (1998) on asymmetric information find that the predictability of real estate returns is generally more indicative of portfolio rebalancing effects than an adverse selection problem, in contrast Yang et.al (2008) find that all the measures of asymmetric information explain a significant portion of the cross-sectional variation in foreign share discounts. Zheng and Narayan (2008) agree with Yang et.al but the on the contrary find that to the theoretical conjecture, asymmetric information has a very weak effect on market returns on the SHSE. Li et. al (2014) concludes that they find that stocks with higher information asymmetry experience higher excess returns. Despite this literature the study falls short where cooper et.al reports on asymmetric information on real estate returns but does not report on stock returns, and also, they use filter-rule methodology and fail to give results on probability information trading as a proxy. Yang, et al (2008) presents results on probability information trading but fails to present results on Volume synchronized information trading and further present results on foreign share discount and fails to report on equity shares. On the other hand, Zheng and Narayan (2009) reports on asymmetric information on market collapse and not asset returns. Li et.al (2014) focuses on international markets and fails to report on Kenyan capital markets. Little is, therefore, known regarding the relationship between asymmetric information and asset returns in Kenyan capital markets.

\section{Research Methodology}

This study adopted longitudinal and correlation research design. According to Bryman \& Bell (2011), in longitudinal study causal inference can be made in certain cases by analyzing data collected over set time-span which offers researchers the opportunity to gauge trends. (Bryman \& Bell, 2011). Barbie, (2010) describes longitudinal study as one which is designed to permit observation of the same phenomenon over an extended period. He further describes three types of longitudinal study; first trend analysis which is a type of longitudinal design in which a given characteristic of some population is observed over time; secondly cohort analysis in which some specific sub population, or cohort, is studied over time, although data maybe collected from different members in each set of observation; thirdly Panel analysis which is a type of analysis in which data are collected from the same set of people at several points. This research will apply retrospective longitudinal research design. This study adopted trend analysis since it will enable the researcher examine the change or stability of asymmetric information, and asset returns. Correlation research design, will determine the extent to which two factors are related. (Privitera \& Wallace 2011) define a correlation research design as the measurement of two factors or more factors to estimate the extent to which those values for the factors are related or change in an identifiable pattern. 


\subsection{Model Specification}

Multiple regression model used to denote the dependent variable and independent variables as follows:

Where:-

$$
R_{i, t}=\gamma_{t}+\gamma_{t} \widehat{\beta_{p, t-1}}+\gamma_{t} S_{i z e_{i, t-1}}+\gamma_{t} B / M_{i, t-1}+\gamma_{t} A S Y M_{i, t-1}+\varepsilon_{i, t}
$$

$R_{i_{i} t}$ : denotes the excess return of stock $i$ of month $t$.

$\overline{\beta_{p, t-1}}$ : denotes stock beta, which is the same for all stocks in the portfolio $\mathrm{P}$ using the data for the previous 12 months.

Size $_{i, t-1}$ : is the log of market value of equity for month $t-1$.

$B / M_{i, t-1}:$ is the book value over market value for month $t-1$.

$A S Y M_{i, t-1}$ : is the measure of asymmetric information of stock $i$ of month $t-1$. The Volume Coefficient variation was used as a measure of Asymmetric information.

$\varepsilon_{i, t}:$ is the error term where $\varepsilon_{t} \sim \operatorname{IId}\left(0, \sigma_{\varepsilon}^{2}\right)$

we control for the effect of beta, size and the book-to-market ratio, since they influence the outcome of the study.

\subsection{Data Collection and Data Analysis}

Purposively the study used monthly transaction on the 20 equities used in formulation of the NSE 20 share index over the period between Jan 2009 and up to March 2018 which formed 111 data points. The stocks in the index were used because they represent a particular portion of the broader market and an index is imaginary portfolio of securities, furthermore they actively trade on a daily basis in the exchange therefore giving a true picture of the market. The period of 9 years and 3 months was selected and would capture milestones that affect the capital market, including the financial crisis of 2008, change of governance over this period, and the financial recession in 2009 to 2011.

The study used descriptive statistic to check the general behaviour of the data. The mean and the variance are the first and second moments of a distribution respectively, and the (standardized) third and fourth moments are known as the skewness and kurtosis respectively. Skewness defines the shape of the distribution, and measures the extent to which it is not symmetric about its mean value. When the distribution of data is symmetric and unimodal (i.e., it only has one peak rather than many), the three methods for calculating the average (mean, mode and median) of the sample will be equal. If the distribution is positively skewed (where there is a long right-hand tail and most of the data are bunched over to the left), the ordering will be mean $>$ median $>$ mode, whereas if the distribution is negatively skewed (a long-left hand tail and most of the data bunched on the right), the ordering will be the opposite. A normally distributed series has zero skewness (i.e., it is symmetric). Kurtosis measures the fatness of the tails of the distribution and how peaked at the mean the series is. A normal distribution is defined to have a coefficient of kurtosis equal to 3 . It is possible to define a coefficient of excess kurtosis, equal to the coefficient of kurtosis minus 3; a normal distribution will thus have a coefficient of excess kurtosis of zero, (Brooks, 2012)

The extent and direction of the relationship between, Asymmetric information and Equity Returns was determined using Pearson's correlation analysis which is widely used in statistic to measure the degree of relationship between the variables. (Vanatta \& Mertler, 2010);( Cohen et. al, 2013). The formula will be given by,

$$
r=\frac{\sum_{i=1}^{n}\left(x_{i}-x\right)\left(y_{i}-y\right)}{\sqrt{\sum_{i=1}^{n}\left(x_{i}-x\right)^{2}} \sqrt{\sum_{i=1}^{n}\left(y_{i}-y\right)^{2}}}
$$

\subsection{Unit Root Tests}

A random or stochastic process is a collection of random variables ordered in time and it is said to be stationary if its mean and variance are constant over time and the value of the covariance between the two time periods depends only on the distance or gap or lag between the two time periods and not the actual time at which the covariance is computed (Gujarati,2004). The implications of unit roots in time series data are, at least potentially profound (Greene, 2012). Firstly, if a time series is stationary, it can strongly influence its behavior and properties, e.g. For a stationary series, 'shocks' to the system will gradually die away. That is, a shock during time $t$ will have a smaller effect in time $t+1$, a smaller effect still in time $t+2$, and so on (Brooks, 2014). Secondly the use of non-stationary data could lead to spurious regression, that is a regression that 'looks' good under standard measures (significant coefficient estimates and a high $\mathrm{R}^{2}$ ), but which is really valueless (Brooks, 2014). Thirdly if the variables employed in a regression model are not stationary, then it can be proved that the standard assumptions for asymptotic analysis will not be valid. In other words, the usual 't-ratios' will not follow a t-distribution, and the F-statistic will not follow an F-distribution.

A time series that is not stationary is defined as non-stationary time series (Brooks, 2014), for a nonstationary series $y_{t}$ to become stationary it must be differenced $d$ times and it is said to be integrated of order $d$ (Brooks, 2014). A series $y_{t}$ is said to be integrated of order one, denoted I(1), because taking a first difference 
produces a stationary process. A nonstationary series is integrated of order $\mathrm{d}$, denoted $\mathrm{I}(\mathrm{d})$, if it becomes stationary after being first differenced d times (Greene, 2012). A test for stationarity that has become popular over the years is unit root test. (Gujarati, 2004). This study applied Augmented Dickey Fuller (ADF) test, The Phillips-Perron (PP) and Kwiatkowski-Phillips-Schmidt-Shin (KPSS) test to test for unit roots.

The Augmented Dickey Fuller Test (ADF), test the null hypothesis that a time series $y_{t}$ is $I(0)$, assuming that the dynamics in data have an ARMA structure (Wang and Zivot, 2006). It is designed to take into account the presence of autocorrelation. It is given as follows: -

Where;

$$
\Delta y_{t}=\beta_{0}+\delta y_{t-1}+\sum_{i=1}^{q} \gamma_{i} \Delta y_{t-1}+\varepsilon_{i}
$$

$y_{t-1}=$ Lag 1 of timeseries and delta $y_{t-1}$ is the first difference of time series at time t-1

The ADF test is unable to discriminate clearly between non-stationarity and stationarity series with a higher degree of autocorrelation and it is sensitive to breaks.

Phillips and Perron (1988) developed a number of unit root tests that have become popular in the analysis of financial time series. The Philips-Perron (PP) unit root tests differs from the ADF test mainly in how they deal with serial correlation and heteroskedasticity in the errors. In particular, where the ADF tests use a parametric autoregression to approximate the ARMA structure or the errors in the test regression, the PP tests ignore any serial correlation (Wang and Zivot, 2006). The study also applied Kwiatkowski, Phillips, Schmidt and Shin, 1992 (KPSS) test where the null hypothesis is stationary and the alternate is a unit root, just the opposite hypothesis of ADF and PP unit root test.

\subsection{Cointegration Test}

According to the co-integration theory, there may be co-integration relationship between the variables involved if they are 1 st order integration series, i.e. their $1^{\text {st }}$ difference is stationary (Masood et.al, 2010). So if $x_{t} \sim I(1)$ then by definition $\Delta x_{t} \sim I(0)$. There are two methods to examine this cointegration relationship, one is EG twostep procedure, put forward by Engle and Granger in 1987, the other is Johansen cointegration test (Johansen(1988) and Juselius1990) based on Vector Auto Regression (VAR). The study applied Johansen's multivariate cointegration tests.

The Johansen's multivariate co-integration (Johansen, 1988) and (Juselius, 1990) test involves testing the relationships between the variables following the vector auto-regression (VAR) model. He proposes two different likelihood ratio tests namely, the trace test and the maximum eigenvalue test. The trace test tests the null hypothesis of $r$ cointegrating vectors against the alternative hypothesis of $n$ cointegrating vectors. If $r=0$, it means that there is no relationship among the variables that is stationary while maximum eigenvalue test, on the other hand, tests the null hypothesis of $r$ cointegrating vectors against the alternative hypothesis of $(r+1)$ cointegrating vectors. This procedure is a vector cointegration test method and has the advantage over the EngleGranger and the Phillips-Ouliaris methods in that it can estimate more than one cointegration relationship, if the data set contains two or more time series, (Ssekuma, 2011)

\section{Results and Discussions.}

\subsection{Descriptive statistics}

Table 4.1 Descriptive Statistics

\begin{tabular}{|l|l|l|l|l|l|}
\hline & RETURNS & BETA & SIZE & PRICE_BOOK & ASYM \\
\hline Mean & 0.000326 & 0.414996 & 10.81969 & 1.772973 & 1.432033 \\
\hline Median & 0.000556 & 0.421973 & 10.90208 & 1.700000 & 1.407601 \\
\hline Maximum & 0.007958 & 0.759023 & 10.96729 & 2.300000 & 2.003396 \\
\hline Minimum & -0.012634 & 0.027430 & 10.55234 & 1.500000 & 1.098304 \\
\hline Std. Dev. & 0.002877 & 0.208097 & 0.153536 & 0.238916 & 0.181741 \\
\hline Skewness & -0.648949 & -0.085332 & -0.719432 & 0.985220 & 0.402034 \\
\hline Kurtosis & 6.326579 & 2.557018 & 1.820800 & 2.991961 & 2.692222 \\
\hline & & & & & \\
\hline Jarque-Bera & 58.97183 & 1.042287 & 16.00640 & 17.95749 & 3.428288 \\
\hline Probability & 0.000000 & 0.593841 & 0.000334 & 0.000126 & 0.180118 \\
\hline & & & & & 158.9557 \\
\hline Sum & 0.036238 & 46.06458 & 1200.986 & 196.8000 & 3.633283 \\
\hline Sum Sq. Dev. & 0.000911 & 4.763468 & 2.593047 & 6.278919 & \\
\hline & & & & & 111 \\
\hline Observations & 111 & 111 & 111 & & \\
\hline
\end{tabular}

Table 4.1 explores descriptive statistics to check the general behaviour of the data. The average Returns of the Kenyan equity market are 0.000326 with a maximum return of 0.000556 and a minimum 0 f -0.012634 for 
the period between 2009 and 2018. The null hypothesis was that all the variables are normally distributed while the alternate hypothesis was that the variables are non-normally distributed. From Table 4.1 shows that data on RETURNS, SIZE, PRICE_BOOK do not support the supposition the variables are normally distributed, hence rejecting the null hypothesis that these variables are normally distributed based on their Jarque- Bera P-Values which are less than 5\%. On the other hand, BETA and ASYM have higher Jarque Bera P-values of 0.59 and 0.18 greater than 0.05 indicating that the data on these two variables is normally distributed. Kurtosis measures the fatness of the tails of the distribution and how peaked at the mean the series is (Brooks, 2012). Kurtosis values of less than 3 are called platykurtic (fat or short-tailed), and those with values greater than 3 are called leptokurtic (slim or long tailed). Kurtosis value of 3 is known as mesokurtic, of which the normal distribution (Gujarati, 2004). Table 4.1 indicates that RETURNS are Leptokurtic since they have a value greater than 3 and SIZE, PRICE_BOOK, and ASYM have values less than 3 hence they are Platykurtic. ASYM PRICE_BOOK are Positively skewed indicating that observed values of these variables have a longtail to the right, large values or a positive side, while RETURNS, BETA and SIZE are negatively skewed.

\subsection{Correlation Analysis}

Table 4.2 Correlation between Returns and Regressors

\begin{tabular}{|c|c|c|c|c|c|}
\hline \multicolumn{2}{|l|}{ Correlation } & \multirow[b]{2}{*}{ BETA } & \multirow[b]{2}{*}{ SIZE } & & \multirow[b]{2}{*}{ ASYM } \\
\hline Probability & RETURNS & & & PRICE BOOK & \\
\hline \multirow[t]{2}{*}{\begin{tabular}{|l|} 
RETURNS \\
\end{tabular}} & 1.000000 & & & & \\
\hline & \begin{tabular}{l|}
----- \\
\end{tabular} & & & & \\
\hline & & & & & \\
\hline \multirow[t]{2}{*}{ BETA } & -0.069548 & 1.000000 & & & \\
\hline & $(0.4683)$ & ----- & & & \\
\hline & & & & & \\
\hline \multirow[t]{2}{*}{ SIZE } & 0.196003 & -0.538996 & 1.000000 & & \\
\hline & $(0.0392)$ & $(0.0000)$ & ----- & & \\
\hline & & & & & \\
\hline \multirow[t]{2}{*}{ PRICE_BOOK } & -0.129999 & -0.655576 & 0.310925 & 1.000000 & \\
\hline & $(0.1739)$ & $(0.0000)$ & $(0.0009)$ & ----- & \\
\hline \multirow[t]{2}{*}{ ASYM } & 0.087823 & -0.294213 & 0.304026 & -0.135253 & 1.000000 \\
\hline & $(0.3594)$ & $(0.0017)$ & $(0.0012)$ & $(0.1570)$ & ----- \\
\hline
\end{tabular}

From table 4.2, the association between Asymmetric Information and Returns were found to be weakly positively correlated and insignificant, $r(99)=.08, p=.35$. The variables Returns and Beta were found to be statistically insignificant and weakly negatively correlated $r(99)=-.06, p=.46$. There was also a weak negative correlation between Returns and Price to book, $r(99)=-.12, p=.17$. Returns and Size also present a weak positive association $r(99)=.19, p=.03$ which was also insignificant.

4.3 Unit Root Test

Table 4.3:Individual Unit Root Test

\begin{tabular}{|c|c|c|c|c|c|c|}
\hline \multirow[t]{2}{*}{ Variables } & \multicolumn{2}{|l|}{$\begin{array}{l}\text { Augmented } \\
\text { (ADF) Test }\end{array}$} & \multicolumn{2}{|c|}{ Phillips Perron (PP)Test } & \multicolumn{2}{|c|}{$\begin{array}{l}\text { Kwiatkowski-Phillips- } \\
\text { Schmidt-Shin (KPSS) } \\
\text { test statistic }\end{array}$} \\
\hline & Intercept & $\begin{array}{l}\text { Intercept } \quad \& \\
\text { Trend }\end{array}$ & Intercept & $\begin{array}{l}\text { Intercept \& } \\
\text { Trend }\end{array}$ & Intercept & $\begin{array}{l}\text { Intercept \& } \\
\text { Trend }\end{array}$ \\
\hline & t-Statistic & t-Statistic & t-Statistic & t-Statistic & $\begin{array}{c}\text { LM- } \\
\text { Statistic }\end{array}$ & $\begin{array}{c}\text { LM- } \\
\text { Statistic }\end{array}$ \\
\hline \multicolumn{7}{|c|}{ At Levels } \\
\hline RETURNS & $\begin{array}{c}-4.7999 * * \\
(0.0001)\end{array}$ & $\begin{array}{c}-4.7768 * * \\
(0.0009)\end{array}$ & $\begin{array}{c}-8.1793^{* *} \\
(0.0000)\end{array}$ & $\begin{array}{c}-8.2914 * * \\
(0.0000)\end{array}$ & 0.2080 & 0.0583 \\
\hline BETA & $\begin{array}{l}-1.5218 \\
(0.5190)\end{array}$ & $\begin{array}{l}-2.1997 \\
(0.4847)\end{array}$ & $\begin{array}{c}-1.564 \\
(0.4975)\end{array}$ & $\begin{array}{c}-2.2792 \\
0.4413\end{array}$ & $0.5862 * *$ & $0.1301^{*}$ \\
\hline SIZE & $\begin{array}{l}-0.8134 \\
(0.8107)\end{array}$ & $\begin{array}{l}-2.1307 \\
(0.5221)\end{array}$ & $\begin{array}{l}-2.0771 \\
(0.2543)\end{array}$ & $\begin{array}{l}-2.6242 \\
(0.2707)\end{array}$ & $0.8743 * *$ & 0.0778 \\
\hline PRICE_BOOK & $\begin{array}{l}-1.6597 \\
(0.4488)\end{array}$ & $\begin{array}{l}-1.6527 \\
(0.7654)\end{array}$ & $\begin{array}{l}-1.6987 \\
(0.4291)\end{array}$ & $\begin{array}{l}-1.6918 \\
(0.7485)\end{array}$ & 0.1396 & $0.1421^{*}$ \\
\hline ASYM & $\begin{array}{l}-1.9549 \\
(0.3063)\end{array}$ & $\begin{array}{c}-3.8544 * * \\
(0.0174)\end{array}$ & $\begin{array}{c}-5.4427 * * \\
(0.0000)\end{array}$ & $\begin{array}{c}-7.0939 * * \\
(0.0000)\end{array}$ & $0.8760 * *$ & $0.2127 * *$ \\
\hline
\end{tabular}




\begin{tabular}{|c|c|c|c|c|c|c|}
\hline \multicolumn{7}{|c|}{ At First Difference } \\
\hline \multirow{2}{*}{$\Delta$ RETURNS } & $\begin{array}{c}-5.1919^{* *} \\
(0.0000)\end{array}$ & $\begin{array}{c}-5.1741^{* *} \\
(0.0002)\end{array}$ & $\begin{array}{c}-21.8464^{* *} \\
(0.0000)\end{array}$ & $\begin{array}{c}-21.931^{* *} \\
(0.0000)\end{array}$ & 0.4282 & $0.4385^{* *}$ \\
\hline \multirow{2}{*}{$\Delta$ BETA } & $\begin{array}{c}-10.3554^{* *} \\
(0.0000)\end{array}$ & $\begin{array}{c}-10.3305^{* *} \\
(0.0000)\end{array}$ & $\begin{array}{c}-10.3554^{* *} \\
(0.0000)\end{array}$ & $\begin{array}{c}-10.3305^{* *} \\
(0.0000)\end{array}$ & 0.0852 & 0.0734 \\
\hline \multirow{2}{*}{$\Delta$ SIZE } & $\begin{array}{c}-5.6554^{* *} \\
(0.0000)\end{array}$ & $\begin{array}{c}-5.4347^{* *} \\
(0.0001)\end{array}$ & $\begin{array}{c}-10.3988^{* *} \\
(0.0000)\end{array}$ & $\begin{array}{c}-10.3739^{* *} \\
(0.0000)\end{array}$ & 0.0615 & 0.0418 \\
\hline DRICE_BOOK & $\begin{array}{c}-10.3572^{* *} \\
(0.0000)\end{array}$ & $\begin{array}{c}-10.3096^{* *} \\
(0.0000)\end{array}$ & $\begin{array}{c}-10.3572^{* *} \\
(0.0000)\end{array}$ & $\begin{array}{c}-10.3096^{* *} \\
(0.0000)\end{array}$ & 0.0995 & 0.0970 \\
\hline \multirow{2}{*}{$\Delta$ ASYM } & $\begin{array}{c}-10.0483^{* *} \\
(0.0000)\end{array}$ & $\begin{array}{c}-10.0045^{* *} \\
(0.0000)\end{array}$ & $\begin{array}{c}-54.043^{* *} \\
0.0001)\end{array}$ & $\begin{array}{c}-54.7217^{* *} \\
(0.0001)\end{array}$ & 0.3211 & $0.2022^{* *}$ \\
\hline
\end{tabular}

Notes: - The Null hypothesis is that the series has a unit root. For ADF and PP the Probability based on MacKinnon (1996) one-sided p-values and KPSS the Probability based on Kwiatkowski-Phillips-Schmidt-Shin (1992, Table 1). Lag Length based on AIC. (*) Significant at the 10\%; (**) Significant at the 5\%; $(* * *)$ Significant at the $1 \%$. The parenthesized values represent the probability while $\Delta$ denotes the first difference

Results in Table 4.3 indicate based on the ADF and PP that not all the variables are stationary at levels, interestingly RETURNS are stationary at levels in both ADF and PP where their P-values at order zero are less than 0.05 . Using PP test variables ASYM is stationary at $I(0)$ leading to the rejection of the null hypothesis. For the other variables we accept the null hypothesis $\delta=0$, these variables have to be differenced that is integrated of order one $I(1)$ in order to achieve stationarity. At first difference all the variables in both ADF and PP test have P values less than 0.05 confirming that they are stationary and therefore rejecting the null hypothesis $(\delta=0)$ that there is a unit root in the variables. Using KPSS we reject the null hypothesis of stationarity process at level $(I(0))$ for variables, BETA, SIZE and ASYM at 5\% critical value according to Kwiatkowski-Phillips-Schmidt-Shin (1992, Table 1). However, at first difference $I(1)$ all the variables are stationary at $5 \%$ significance level. Graphically stationarity for Asymmetric information and Equity Returns can be represented as follows: -

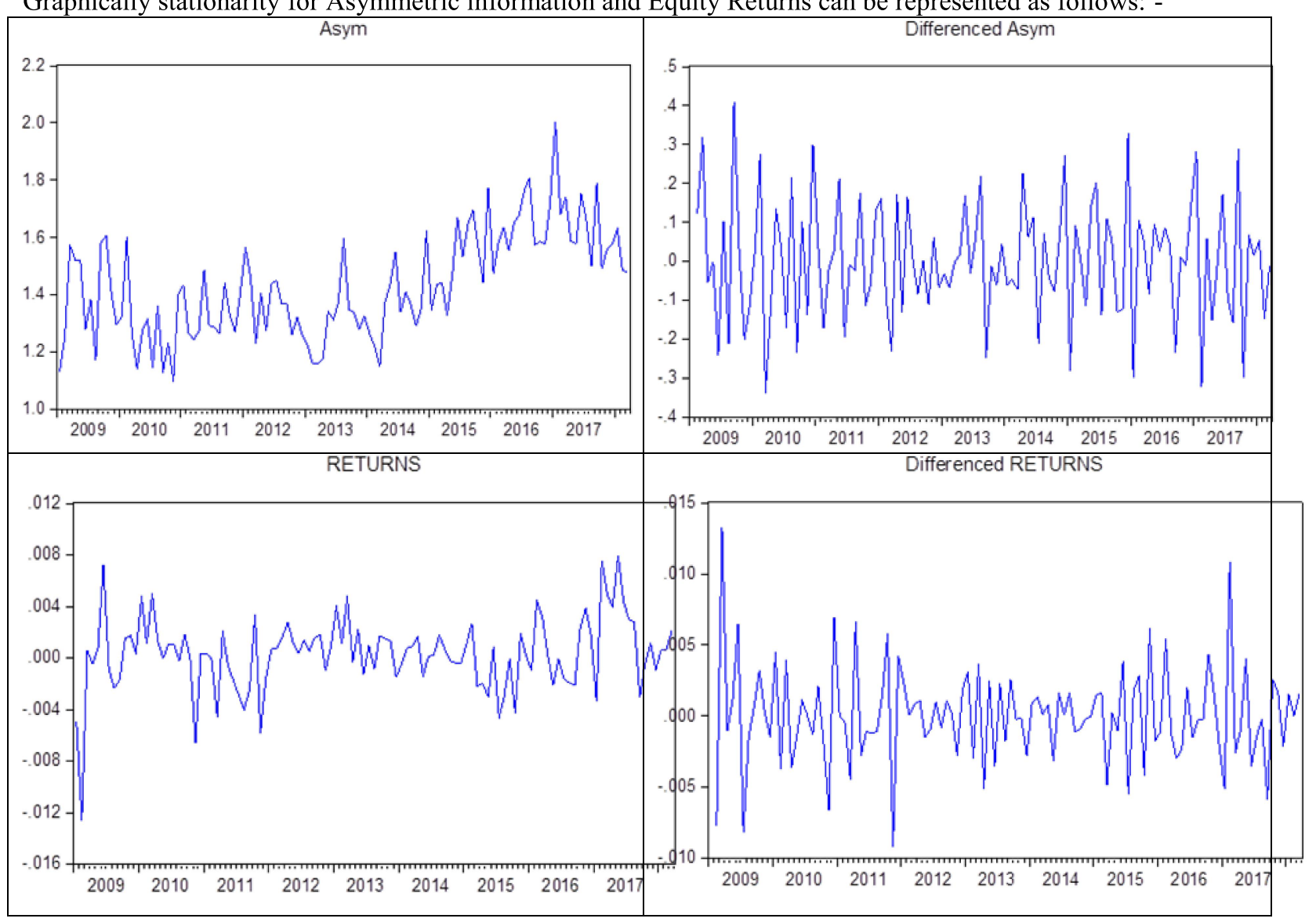

Figure 1 Stationarity for Asymmetric Information And Equity Returns

4.4 Cointegration Test.

To test whether there is co-integration relationship between the variables, Johansen cointegration test was used. 
Table 4.5 shows the results

Table 4.4 Johansen Cointegration test

\begin{tabular}{|c|c|c|c|c|}
\hline \multicolumn{4}{|c|}{ Unrestricted Cointegration Rank Test (Trace) } & \\
\hline Hypothesized & & Trace & 0.05 & \\
\hline No. of $\mathrm{CE}(\mathrm{s})$ & Eigenvalue & Statistic & Critical Value & Prob.** \\
\hline None $*$ & 0.435847 & 187.0324 & 125.6154 & 0.0000 \\
\hline At most $1 *$ & 0.419553 & 124.6376 & 95.75366 & 0.0001 \\
\hline At most 2 & 0.246221 & 65.34642 & 69.81889 & 0.1080 \\
\hline At most 3 & 0.162159 & 34.53693 & 47.85613 & 0.4727 \\
\hline At most 4 & 0.094233 & 15.25190 & 29.79707 & 0.7635 \\
\hline At most 5 & 0.030858 & 4.463782 & 15.49471 & 0.8628 \\
\hline At most 6 & 0.009562 & 1.047222 & 3.841466 & 0.3061 \\
\hline \multicolumn{5}{|c|}{$\begin{array}{l}\text { Trace test indicates } 2 \text { cointegrating eqn(s) at the } 0.05 \text { level } \\
* \text { denotes rejection of the hypothesis at the } 0.05 \text { level } \\
* * \text { MacKinnon-Haug-Michelis (1999) p-values }\end{array}$} \\
\hline \multicolumn{5}{|c|}{ Unrestricted Cointegration Rank Test (Maximum Eigenvalue) } \\
\hline Hypothesized & & Max-Eigen & 0.05 & \\
\hline No. of CE(s) & Eigenvalue & Statistic & Critical Value & Prob.** \\
\hline None $*$ & 0.435847 & 62.39476 & 46.23142 & 0.0005 \\
\hline At most $1 *$ & 0.419553 & 59.29122 & 40.07757 & 0.0001 \\
\hline At most 2 & 0.246221 & 30.80949 & 33.87687 & 0.1113 \\
\hline At most 3 & 0.162159 & 19.28503 & 27.58434 & 0.3928 \\
\hline At most 4 & 0.094233 & 10.78811 & 21.13162 & 0.6684 \\
\hline At most 5 & 0.030858 & 3.416560 & 14.26460 & 0.9152 \\
\hline At most 6 & 0.009562 & 1.047222 & 3.841466 & 0.3061 \\
\hline \multicolumn{5}{|c|}{$\begin{array}{l}\text { Max-eigenvalue test indicates } 2 \text { cointegrating eqn(s) at the } 0.05 \text { level } \\
* \text { denotes rejection of the hypothesis at the } 0.05 \text { level } \\
* * \text { MacKinnon-Haug-Michelis (1999) p-values }\end{array}$} \\
\hline
\end{tabular}

Table 4.5 Normalized cointegrating equation

\begin{tabular}{|c|c|c|c|c|}
\hline RETURNS & BETA & SIZE & PRICE_BOOK & ASYM \\
\hline 1.000000 & 0.007835 & 0.000976 & 0.008866 & 0.009370 \\
\hline & $(0.00316)$ & $(0.00339)$ & $(0.00264)$ & $(0.00286)$ \\
\hline
\end{tabular}

From Table 4.4 the null hypothesis of no cointegration $(r=0)$ against the alternative of presence of one or more cointegrating vector is rejected at the $5 \%$ level of significance in both techniques (trace test and maximum eigenvalue). This implies there exist a long run relationship between RETURNS, BETA, SIZE, PRICE_BOOK, ASYM. From Table 4.5 we can interpret that a decrease of $0.0093 \%$ in asymmetric information is associated with an increase in equity returns in the long run and vice versa. This is consistent with results by Narayan and Zheng, (2010) who found out that asymmetric information has a very weak effect on market returns on the Shanghai Stock Exchange (SHSE): where only around 11\% of cases asymmetric information has a statistically significant negative effect on market returns. And it contrasts with Li et. al (2014) who concluded that stocks with higher information asymmetry experience higher excess returns, since the change is quite small.

\subsection{Conclusion}

The study examined the cointegration analysis on the relationship between asymmetric information and equity returns and data gathered from the capital market, the correlation between asymmetric information and the effect thereof show relative low influence on equity returns. The study also revealed a significant long run relationship between Asymmetric information and Equity returns, that is a negative change in asymmetric information will have a significant positive effect on equity returns in the Kenyan capital markets and vice-versa.

\section{REFERENCES}

Aboody, D., Lev, B. (2000). "Information Asymmetry, R\&D, and Insider Gains". Journal of Finance 55 (6): 2747-276

Allen, F., Brealey, R., \& Myers, S., (2011). Principles of Corporate Finance. New York McGraw Hill Irwin.

Andersen, T., Bollerslev, T., \& Diebold, F., (2003). Micro Effects of Macro Announcement: Real Time price discovery in foreign exchange. American Economic Review, 93(3) 38-62 DOI:10.3386/w8959

Akerlof, G.A. (1970). The market for lemons: Quality uncertainty and the Market Mechanism, Quarterly 
Journal of Economics. 84(3), 488-500.

Babbie, E. (2010) The practice of social research. 12th Edition, Wadsworth, Belmont.

Blume, L., \& Durlauf, S. (2008). The New Palgrave Dictionary of Economics. New York: Palgrave Macmillan

Brooks, C. (2012). Introductory econometrics for finance. Cambridge: Cambridge University Press.

Brooks, C. (2014). Introductory econometrics for finance. Cambridge: Cambridge University Press.

Brown A.L. (2016). Asymmetric Information. In: Augier M., Teece D. (eds) The Palgrave Encyclopedia of Strategic Management. Palgrave Macmillan, London. https://doi.org/10.1057/978-1-349-94848-2_458-1

Brown, S., Hillegeist, S., \& Lo, K., (2008). The effect of earnings surprises on information Asymmetry. Journal of Accounting and Economics. 47(3), 208-225 DOI 10.1016/j.jacceco.2008.12.002

Bryman, A. \& Bell, E. (2011). Business Research Methods Oxford: Oxford University. Ebook

Capital Market Authority, (2014). Capital Market Master Plan 2014- 2023, Kenya.

Capital Market Authority, (2020). A White Paper for Consumer Financial Education Strategy On Capital Markets. SBA Africa Limited

Cappiello, L., Engle, R., \& Sheppard, K., (2003). Asymmetric Dynamics in the correlation of Global equity and bond returns. European Central Bank Working Paper.

CEIC Data, (2020). Kenya Market Capitalization: \% of GDP. ISI Emerging Markets Group Company

Chan, K., Menkiveld, A., \& Yang, Z., (2008). Information asymmetry and Asset prices: evidence From the China foreign share discount. Journal of Finance. 63(1), 159-196

Connolly, R.A. \& Wang F.A. (2003). International equity market co-movements: Economic fundamentals or contagion? Pacific Basin Finance Journal, 11 (2003), pp. 23-43

Cohen, J. Cohen, P., \& West, S., (2013). Applied Multiple Regression/Correlation Analysis for the Behavioural Sciences. London: Lawrence Erabaum Publishers

Coopers, M., Downs, D. \& Patterson, G., (1998) Asymmetric Information and Predictability of Real Estate Returns. Journal of Real Estate Finance and Economics. 20(2).

Cootner, P., (1964). The Random Character of Stock Market Prices. Cambridge, Mass.: MIT Press.

Creswell, J. (2013). Research Design: Qualitative, Quantitative and Mixed Methods Approaches. (4 ${ }^{\text {th }}$ Ed). SAGE publication.

Degutis, A., \& Novickyte, L., (2014). The Efficient Market Hypothesis: A Critical Review of Literature and Methodology. ECONOMIKA.

Ding, S. (2011) Asymmetric Information in Emerging Markets: Lessons from China. Unpublished PhD thesis. Queen's University Canada

Eakins, G., \& Mishkin, S., (2012). Financial Institution and Markets. Boston Prentice Hall.

Easley, D. \& O'Hara, M., 2004. Information and the cost of capital. Journal of Finance, 59(4), 1553-1583

Easley, D., De Prado, M., O’Hara, M. 2011. The Microstructure of the flash crash: Flow toxicity, Liquidity Crashes and the probability informed trading. The Journal of portfolio Management 37(2), 118-128

Easley, D., Hvidkjear, S., O'Hara, M., 2002. Is information Risk a Determinant of Asset returns? Journal of Finance. 57(5), 2185-2221

Fama, E., 1970. Efficient Capital Markets: A review of Theory and Empirical Work. The Journal of Finance, 25(2), 383-417

Fama, E., (1991a). Efficient Capital Market II. Journal of Finance, 46(5), 1575-1617

Fama, E. \& French, K (1988). "Permanent and Temporary Components of Stock Prices." Journal of Political Economy, 96(2), 246-273

Farlex, (2012). Free finance encyclopaedia. https://financialdictionary.thefreedictionary.com/

Greene, W. (2012) Econometric Analysis. 7th Edition, Prentice Hall, Upper Saddle River.

Goedhart, M., Koller, T., Wessels, D., (2010). Valuation. New Jersey: John Wiley's and Sons.

Gosalia, K., and Lefebvre, R., (2013). Empirical Testing of Momentum Effect in Canadian Capital Markets. Certified General Accountants Association of Canada.

Gujarati, D.N. (2004). Basic Econometrics. 4th Edition, McGraw-Hill Companies.

Johansen, S. \& Jesulius, K., (1990) Maximum Likelihood Estimation and Inference on Cointegration-with Application to the Demand of Money. Oxford Bulletin of Economic and Statistics.

Johansen, S., (1988). Statistical analysis of cointegration vectors. Journal of economic Dynamicsand Control. 12(3), 231-254

Kemei J., \& Kerongo, F., 2014. The Effects of Information Asymmetry in the Performance of the Banking Industry: A Case Study of Banks in Mombasa County. Unpublished master thesis. Jomo Kenyatta University of Agriculture and Technology

Li, G. (2008). Liquidity, Information Asymmetry, Divergence of Opinion and Asset Returns Evidence from Chinese Stock market. University of California USA.

Li, G., Lu, L., Wu, B., Zhang, Z., (2014). Asymmetric information, illiquidity and asset returns: evidence from China. Quantitative Finance, United Kingdom. 
Lo, Andrew W., Mamaysky, H., \& Wang, J., (2000). "Foundations of Technical Analysis: Computational Algorithms, Statistical Inference, and Empirical Implementation.” Journal of Finance, 55(4), 1705-1765

Lof, M. \& van Bommel, J. (2018) Asymmetric Information and the Distribution of Trading Volume 2018. Bank of Finland Research Discussion Paper No. 1/2018, Available at SSRN: https://ssrn.com/abstract=3106595

Malkiel, B.G. (2003). The Efficient Market Hypothesis and its Critics. The Journal of Economic Perspectives, 17(1), 59-82, Doi. 10.1257/089533003321164958

Malkiel, B., (2011). The Efficient- Market Hypothesis and the Financial Crisis. Rethinking Finance perspectives on the crisis. Russell sage Foundation.

Mertler, C. A., \& Vannatta, R. A. (2010). Advanced and multivariate statistical methods: Practical application and interpretation (4th ed.). Pyrczak.

Morse, D. (1980) Asymmetric information in securities markets and trading volume. Journal of financial and quantitative analysis, 2, 171-141

Nuryaman, (2014). The Influence of Asymmetric Information on the Cost of Capital with the Earnings Management as Intervening Variable. Journal of Advanced Management Science.

Palan, S., (2004). The efficient market hypothesis and its validity to today's markets. Master Thesis KarlFranzens University, Graz.

Phillips, P.C.B. \& Perron, P. (1988) Testing for a Unit Root in Time Series Regression. Biometrika, 75, 335-346. http://dx.doi.org/10.1093/biomet/75.2.335

Poterba, J. \& Summers, L. (1988). "Mean Reversion in Stock Returns: Evidence and Implications." Journal of Financial Economics, 22(1), 27-59

Privitera, G. J., \& Wallace, M. (2011). An assessment of liking for sugars using the estimated daily intake scale. Appetite, 56, 713-718. Doi: 10.1016/j.appet.2011.02.008

Schwert, G., (2003). Anomalies and the market efficiency. NBER working paper series.

Sharpe, W., \& Alexander, G. (1990), Investments, 4th edition, (Prentice Hall, Englewood Cliffs, N.J.).

Shiller, J., (2000). Irrational Exuberance. Princeton: Princeton University Press.

Shleifer, A. (2000). Inefficient Market. New York: Oxford University Press.

Stroebel, J., \& Kurlat, P., 2013 Knowing Your Neighbourhood: Asymmetric Information in Real Estate Markets. University of Stanford.

Ssekuma, R. (2011), A Study of Cointegration Models with Applications MS Project, University of South Africa

Travis L. Johnson, Eric C. So (2017) A Simple Multimarket Measure of Information Asymmetry. Management Science 64 (3) 1055-1080 https://doi.org/10.1287/mnsc.2016.2608

World Bank (2003) siteresources.worldbank.org/.../Asymmetric_Info_Sep2003. Accessed on 15/5/2015

World Bank (2020), Stock Market Capitalization to GDP for Kenya. Federal Reserve Bank of St. Louis; https://fred.stlouisfed.org/series/DDDM01KEA156NWDB, November 10, 2020.

Yang, Z., Menkveld, A., Chan, K., (2008). Information Asymmetry and Asset Prices: Evidence form the China Foreign Share Discount. Journal of Finance, 63(1), 159-196

Yu M., (2012). Essays on information asymmetry and the firm. PhD Thesis University of Iowa

Zheng, X., \& Narayan, P. (2011). Asymmetric information and market collapse: Evidence from the Chinese market. Deakin University Australia.

Zheng, X., \& Narayan, P., (2009). Asymmetric information and Market Collapse: Evidence from the Chinese Market. Financial Economic Series. Deakin University.

Zivot E. \& Wang J. (2006). Modelling financial time series with S-Plus ${ }^{\circledR}$, volume 191. Springer Science \& Business Media. 